\title{
LIVROS-TEXTO DE ENFERMAGEM
}

Em espaço de tempo relativamente curto nossa profissão atingiu um progresso difícil de ser aquilatado por quem não viveu a história do seu vacilante inicio no Brasil. Levou alguns anos para saır do âmbito restrito do Rio de Janeiro e ganhar espaço nas demais Unidades da Federação. Lutou durante quatro décadas para conseguir que as instituições formadoras dos profissionais de enfermagem ocupassem seu lugar nas universidades brasileiras.

Ao mesmo tempo em que se empenhavam nessas lutas, as enfermeiras, poucas numericamente, mas determinadaś a auxiliarem no desenvolvimento da assistência à saúde, trabalhavam com afinco no sentido de preparar e aperfeiçoar o maior número possivel de profissionais e de pessoal auxiliar. Não foi fácil. Provou, entretanto, que quando as mulheres são movidas por um ideal que reverterá em benefício da cole tividade, agigantam-se em sua luta e trabalho e conseguem o que se poderia qualificar de milagre.

A referência especifica a enfermeiras justifica-se. As maiores conquistas foram conseguidas, entre 1923 e aproximadamente 1972, quando o elemento masculino ainda era raridade na profissão e quase não participava da atividade associa tiva. Hoje, o quadro modificou-se e um grupo coeso de enfermeiras $e$ enfermeiros é o responsável pelo grande progresso da profissão-associação de classe forte e combativa; congressos anuais dos mais concorridos, onde temas de alta importância e qualidade científica são discutidos por uma audiência culta e esclarecida; encontros regionais de profissionais de áreas afins, nos quais problemas do ensino e do exercicio ocupam a pauta dos trabalhos; órgãos de divulgação científica que nada deixam a dever aos jornais e revistas de outras profissões; desenvolvimento da pesquisa de enfermagem com trabalhos de alto significado para o progresso da enfermagem e para o aperfeiçoamento da assistência à saúde da coletividade.

Entretanto, a producão de livros-texto de enfermagem não acompanhou todo esse desenvolvimento da parte científica e do exercício profissional no País. Nossos estudantes ainda não se beneficiam de livros didáticos como auxilio para o seu crescimento no período escolar. Existem alguns poucos, principalmente traduções de livros norte-americanos, nem sempre bem traduzidos e muitas vezes abordando assuntos fora da realidade ou das necessidades da enfermagem brasileira.

Por que será? O que estará faltando para os enfermeiros começarem a publicar livros-texto para uso dos cursos dos três niveis de ensino - de enfermagem, de técnicos de enfermagem e de auxiliares de enfermagem? Não deverá ser por falta de mercado consumidor, pois de ano para ano o número de novas matrículas nesses cursos cresce satisfatoriamente. Tampouco poderá ser por falta de conhecimentos $e$ recursos literários. A qualidade dos trabalhos e pesquisas apresentados em congressos, ou publicados nas revistas profissionais, atestam esse fato. De maneira nenhuma por culpa das editoras, pois à falta de obras brasileiras estão colocando no mercado as traduções que aparecem, e não são poucas atualmente.

Preocupada com esse problema, a diretoria da ABEn criou recentemente a Comissão Especial do Livro-texto que se propõe a incentivar a produção da literatura profissional no País, orientar e assessorar os interessados na elaboracão de livros didáticos e fazer a divulgação das obras através de comentários, críticas e resenhas nos órgãos de publicidade da Associacăo.

A criação da Comissão Especial do Livro-texto constitui um desafio aos nossos profissionais, principalmente aos que estão ligados ao ensino universitário. Precisamos de livros didáticos em todos os três niveis de ensino e em todas as áreas da enfermagem, especialmen te em administração, história, ética e enfermagem preventiva e comunitária. Temos pessoal capacitado nessas e na área clínica. Quando vamos começar a publicar livros de enfermagem? Quantos enfermeiros estarão dispostos a aceitar o desafio da $A B E n$ ?

\section{Amália Correia Carvalho}

